\title{
Factors associated with adherence to immunomodulator treatment in people with multiple sclerosis
}

\author{
Nair Assunta Antônia Corso Câmara1, Ana Paula Soares Gondim²,* \\ ${ }^{1}$ Fortaleza General Hospital, HGF, Fortaleza, Ceará, Brazil, ${ }^{2}$ Department of Pharmacy, Faculty of Pharmacy, Dentistry and \\ Nursing, Federal University of Ceará, UFC, Fortaleza, Ceará, Brazil
}

\begin{abstract}
To determine the association between factors and adherence to immunomodulator treatment in people with multiple sclerosis treated in reference centers. Cross-sectional study conducted with 188 people who used immunomodulators in three reference centers in Ceará from March to July 2012. Adherence was assessed using the Moriskscale and factors were assessed using a questionnaire addressing socioeconomic and personal characteristics, the disease, the use of immunomodulator and educational activities. The determination of the association was expressed in crude and adjusted odds ratio with a $95 \%$ confidence interval. Adherence rate was $46 \%$ and after the logistic regression model the adherence to immunomodulator treatment was positively associated with the following factors: age 18-38 years, time of diagnosis and treatment between 6 and 24 months, 0-3.5 score in the Expanded Disability Status Scale, perception of treatment benefits, intrinsic and extrinsic motivation, phone contact with the doctor and not missing the return visit. This study is important because it allowed to determine the association between factors and adherence to immunomodulator treatment in multiple sclerosis, contributing to prevention and control actions.
\end{abstract}

Uniterms: Multiple sclerosis/medication adherence. Multiple sclerosis/treatment. Immunologic factors. Risk factors.

\section{INTRODUCTION}

Medication adherence is essential to the effective treatment of many diseases, particularly the chronic ones (Wolf et al.; 2007; Conn et al., 2016). In people's lives, such adherence can positively contribute to slow down the clinical progression of the disease and improve quality of life. In health services, it can reduce hospitalization costs (World Health Organization, 2003; Sokol et al., 2005).

The World Health Organization (2003) defines adherence to treatment as the extent to which a person's behavior - taking medication, following a diet, and/or executing lifestyle changes - corresponds with agreed recommendations from a health care provider. Some studies show that adherence is influenced by patient's behavior and beliefs such as the benefits and the importance given to health in addition to the type of medication administration

*Correspondence: A. P. S. Gondim. Departamento de Farmácia. Faculdade de Farmácia, Odontologia e Enfermagem. Universidade Federal do Ceará. Rua Capitão Francisco Pedro, 1210, Rodolfo Teófilo, 60.430-372, Fortaleza, Ceará,

Brasil. E-mail: anapaulasgondim@uol.com.br and socioeconomic characteristics (Tremlett et al., 2008; Treadaway et al., 2009; Devonshire et al., 2011; LópezMéndez et al., 2013).

Multiple sclerosis (MS) is a chronic, progressive and disabling inflammatory disorder of the central nervous system (Rio, Comabella, Montalban, 2011) and its treatment includes the continuous use of medications, especially immunomodulators (IM). Given that, adherence to treatment is essential to maximize the benefits of the therapy (Devonshire et al., 2011).

In Brazil, the treatment for MS is provided by the Ministry of Health through the National Health System, also known as the Unified Health System (Sistema Único de Saúde - SUS). Patients must be treated in specialized services with an adequate infrastructure for their monitoring and the fist-line treatment includes the glatiramer acetate and beta interferon (Brasil, 2015). In the state of Ceará, Northeastern Brazil, patients are treated in three Reference Centers linked to high complexity hospitals where they can receive the diagnosis and be monitored. 
This article aims to determine the association between factors and the adherence to immunomodulator treatment in people with multiple sclerosis treated in reference centers.

\section{METHOD}

\section{Type of study}

Cross-sectional study conducted with people with multiple sclerosis treated in Reference Centers in the state of Ceará, Northeastern Brazil, from April to July 2012.

\section{Research locale}

The three Reference Centers for patients with multiple sclerosis of the state of Ceará are run by the SUS and present a proper structure for the diagnosis and treatment of the disease. Two centers are located in the city of Fortaleza, capital of Ceará. One center belongs to a State Hospital and the other is part of the Federal University of Ceará (Universidade Federal do Ceará - UFC). Both centers receive MS patients from all over the state. The third center is located in the state's countryside, about 200 $\mathrm{km}$ from Fortaleza, and provides care to patients from Northern Ceará. The centers receive an average of 140 patients per month.

\section{Study population}

The total population diagnosed with multiple sclerosis or clinically isolated syndrome (CIS) and treated with one of the injectable immunomodulators (intramuscular interferon beta-1a, subcutaneous interferon beta- $1 \mathrm{a}$, interferon beta- $1 \mathrm{~b}$ or glatiramer acetate) included 228 people. All these immunomodulators were dispensed free of charge in the pharmacies of the three Reference Centers.

Inclusion criteria were: patients aged over 18 years old diagnosed with MS or CIS treated in the aforementioned centers with one of the injectable immunomodulators for at least six months. Exclusion criteria were: patients treated with other medications rather than immunomodulators.

\section{Variables of the study}

The dependent variable was the adherence to treatment with immunomodulators assessed by the Morisky Medication Adherence Scale (MMAS-8) (Morisky et al., 2008). The items regarding the inadequate use of medication were: forgetting to take the medication; stopping taking the medication on his/her own when feeling better; stopping taking the medication when feeling worse and problems related to the complexity of the therapy - seven questions should be answered negatively and one should be answered positively.

The degree of adherence to the treatment was determined by the scoring of the sum of all correct answers. Patients who scored eight in the MMAS-8 were considered adherent (Morisky et al., 2008).

Independent variables were: socioeconomic characteristics (marital status, education, monthly household income, paid job, economic status); personal characteristics (gender, color, age, intrinsic and extrinsic motivation); aspects related to the disease (time of diagnosis assessed through medical records and rate of disease progression measured through the Expanded Disability Status Scale-EDSS); aspects related to the use of immunomodulators (length of treatment, difficulties to obtain and administer the IM, perception of the benefits of the use of the IM, who administers the IM, lifestyle changes, side effects caused by the medication); educational actions performed in the health care services (information about the disease and its treatment and on how to contact the doctor, and return to scheduled consultations). These variables were collected through self-reported information.

Economic status: it was measured according to the Brazilian Economic Classification Criteria established by the Brazilian Association of Enterprises and Research (Associação Brasileira de Empresas e Pesquisa) that takes into account the educational level and the number of consumer goods in the household (Associação Brasileira de Empresas de Pesquisa, 2012).

Intrinsic motivation refers to the patient's opportunity to control the disease ("avoid" its progression), his/her hope to avoid episodes and get better, and the perception of improvement of the symptoms. Extrinsic motivation refers to an external influence on the use of the medication caused by the family, health care professionals and friends.

\section{Data collection}

Data were collected by applying a formulary during directive interviews. The form had 155 questions distributed in six parts. The interview was conducted on the day of consultations in the Reference Centers. The interviewees signed the free informed consent form. Data collection occurred simultaneously in the three centers. 


\section{Statistical method}

Data were organized in the SPSS (SPSS Inc., Chicago, USA), version 16.0 and analyzed by the software STATA (STATA Corp LP, College Station, TX 77845 , USA), version 11.0. The exploratory analyses of quantitative variables were performed using measures of central tendency (mean and median) and dispersion (standard deviation) to test for normality of proportions. The categorical variables were presented as proportions.

The chi-square test $(\chi 2)$ was used in the construction of the logistic regression model in which the dependent variable was the adherence to medication treatment and independent variables were the socioeconomic characteristics and characteristics of the disease, treatment and the ones related to the patient and the health care professional. Statistical significance was set at $p<0.05$. The selection of variables for the construction of the multivariate logistic regression model was based on the automatic selection method (stepwise). The strength of association between the dependent variable and the independent variables was expressed by the value of crude and adjusted Odds Ratio (OR) with a 95\% Confidence Interval $(\mathrm{CI})$.

\section{Ethical Aspect}

The study followed all the guidelines of -resolution 466/12 established by the National Health Council and was approved by the Ethics Research Committee of the University of Fortaleza under Opinion No. 445/2012.

\section{RESULTS}

Participants were 188 people with multiple sclerosis treated in the three Reference Centers of Ceará, which corresponded to $84.1 \%$ of the patients registered in the centers; there was a loss of $15.9 \%$ (30) of people who did not participate in the study because they had been using the medications for less than six months and also used other medications. Most of the 188 people with multiple sclerosis undergoing treatment were: under 38 years old (45.8\%), with a mean age of 38.6 years; women $(75.5 \%)$; white $(84.0 \%)$; had a higher education degree $(52.7 \%)$; and were unemployed (56.9\%). Almost half of the patients $(45.7 \%)$ were married; $59.0 \%$ were classified as belonging to income class $\mathrm{A} / \mathrm{B}$ with an average household income of $\mathrm{R} \$ 2,214.89$ per month (Table I).

Most patients had an Expanded Disability Status Scale score (EDSS score) below 3.5 (65.4\%) and the average time of diagnosis and treatment was 73.9 and
64.6 months, respectively. Most patients feel intrinsically motivated to adhere to the treatment $(77.1 \%)$ due to: believing that immunomodulator medication avoids the disease progression (77.3\%), hoping to avoid episodes $(56.9 \%)$ and hoping to get better (42.1\%). Almost all patients feel extrinsically motivated to adhere to the treatment $(88.3 \%)$; they are motivated by the family $(75.0 \%)$ and health care professionals (34.3\%). The benefits of immunomodulator medication was recognized by $55.3 \%$ of participants, and the main benefits mentioned were: reduction of episodes of MS (70.8\%), lighter episodes $(38.1 \%)$, improvement of incapacity $(37.2 \%)$ and delayed disease progression (30.1\%). Many patients reported side effects associated with the use of immunomodulator medication (60.6\%), and the most common were: myalgia $(50.0 \%)$, malaise $(48.1 \%)$, cephalgia $(40.3 \%)$, fatigue $(33.7 \%)$, fever $(25.0 \%)$ and hyperemia $(25.0 \%)$. The difficulty in administering the immunomodulator medication was observed in $59.6 \%$ of participants, and $79.2 \%$ reported no difficulties in obtaining the medication. Most patients received information about the disease (84.6\%) and treatment (90.0\%). Still, more than half of patients reported keeping contact with the doctor of the Center on the day of the consultation only $(59.6 \%)$ and many did not return to medical consultations (49.5\%) (Table II).

According to the Morisky Medication Adherence Scale (MMAS), there was an adherence of $46.0 \%$ and the main causes for non-adherence were: forgetfulness $(64.0 \%)$ and discomfort in continuing the treatment because of its complexity (31.0\%) (Figure 1).

There was statistically significant association between adherence to treatment with IM and the following variables: age under 39, shorter period of treatment, shorter period of diagnosis and lower Expanded Disability Status Scale scores (EDSS scores). Intrinsic motivation, perception of the benefits caused by the treatment and extrinsic motivation are protective factors for the adherence to medication. Regarding the variables related to health care, patients who received information about the disease, contacted the doctor by the phone and on the day of the consultation and never missed their next consultations presented statistical significance. The variables age under 39 , intrinsic motivation, extrinsic motivation, Expanded Disability Status Scale score (EDSS score) below 3.5, length of treatment, perception of the benefits caused by the treatment, contact with the doctor by the phone and on the day of the consultation, and never missing their next consultations were maintained in the adjusted model with statistical significance (Table III). 
TABLE I - Demographic and socioeconomic characteristics of patients with multiple sclerosis receiving care in Reference Centers. Ceará, 2012

\begin{tabular}{|c|c|c|c|c|c|}
\hline Variables & $\mathbf{n}$ & $\%$ & Mean & $\begin{array}{l}\text { Standard } \\
\text { deviation }\end{array}$ & Median \\
\hline \multicolumn{6}{|l|}{ Age (years) $(\mathrm{N}=188)$} \\
\hline $18-38$ & 100 & 53.2 & 38.6 & 12.5 & 37.0 \\
\hline $39-66$ & 88 & 45.8 & & & \\
\hline \multicolumn{6}{|l|}{ Gender $(\mathrm{N}=188)$} \\
\hline Men & 46 & 24.5 & & & \\
\hline Women & 142 & 75.5 & & & \\
\hline \multicolumn{6}{|l|}{ Race/Color (N=185) } \\
\hline White & 158 & 84.0 & & & \\
\hline Pardo & 27 & 14.4 & & & \\
\hline Black & 3 & 1.6 & & & \\
\hline \multicolumn{6}{|l|}{ Marital Status (N=188) } \\
\hline Single/Widow(er)/divorced & 102 & 54.3 & & & \\
\hline Married & 86 & 45.7 & & & \\
\hline \multicolumn{6}{|l|}{ Education ( $N=184)$} \\
\hline Elementary school/High school & 85 & 45.2 & & & \\
\hline Higher education & 99 & 52.7 & & & \\
\hline \multicolumn{6}{|l|}{ Employment (N=171) } \\
\hline Unemployed/retired/disability benefits & 107 & 56.9 & & & \\
\hline Employed & 37 & 19.7 & & & \\
\hline \multicolumn{6}{|l|}{ Household income $(\mathrm{R} \$)(\mathrm{N}=183)$} \\
\hline Up to $2,214.89$ & 134 & 73.2 & $5,205.00$ & $6,241.19$ & $3,000.00$ \\
\hline Above 2,214.89 & 49 & 26.8 & & & \\
\hline \multicolumn{6}{|l|}{ Economic status $(\mathrm{N}=\mathbf{1 8 8})$} \\
\hline $\mathrm{A} / \mathrm{B}$ & 111 & 59.0 & & & \\
\hline $\mathrm{C} / \mathrm{D}$ & 77 & 41.0 & & & \\
\hline
\end{tabular}

\section{DISCUSSION}

This study aimed to determine the association between factors and adherence to immunomodulator treatment in people with multiple sclerosis treated in reference centers and has identified an adherence rate of $46 \%$ according to the Morisky Medication Adherence Scale (MMAS-8) (Morisky et al., 2008). This value was lower than the ones found in studies like a multicenter study conducted in Spain health care centers for MS patients using the Morisky \& Green scale, which found an adherence rate of $68 \%$ (Fernandez et al., 2012).

It is important to say that some of the differences found in the adherence rates of these studies may be explained by the variables established to define adherence (Gordis, 1989). Choosing a cross-sectional study allowed to estimate the proportion of adherence to treatment and its associated factors.

The factors positively associated with adherence identified in this study were: younger age, shorter period of diagnosis and length of treatment, lower EDSS scores, perception of the benefits of the treatment, intrinsic and extrinsic motivation. Additionally, receiving information about the disease, contacting the doctor more often (by phone, for instance) and not missing the next consultations have contributed to the adherence to treatment.

Non-adherence rate was high and it was identified that individuals who were not adherent to the treatment intentionally discontinued the therapy. Another reason was the patient's forgetfulness, which is an unintentional behavior. When it comes to patients with MS, forgetting to take the medication may be associated with alterations 
TABLE II - Aspects related to the disease and treatment of patients with multiple sclerosis receiving care in Reference Centers. Ceará, 2012

\begin{tabular}{|c|c|c|c|c|c|}
\hline Variables & n & $\%$ & Mean & $\begin{array}{l}\text { Standard } \\
\text { deviation }\end{array}$ & Median \\
\hline \multicolumn{6}{|l|}{ Expanded Disability Status Scale ( $\mathrm{N}=188)$} \\
\hline $0-3.5$ & 123 & 65.4 & & & \\
\hline $4-8.0$ & 65 & 34.6 & & & \\
\hline Period of diagnosis (months) $(\mathrm{N}=188)$ & & & 73.9 & 61.9 & 60.0 \\
\hline $6-24$ & 36 & 19.1 & & & \\
\hline More than 24 & 152 & 80.9 & & & \\
\hline Length of treatment (months) $(\mathrm{N}=188)$ & & & 64.6 & 48.6 & 54.5 \\
\hline $6-24$ & 42 & 22.3 & & & \\
\hline More than 24 & 146 & 77.7 & & & \\
\hline \multicolumn{6}{|c|}{ Intrinsic motivation to use the immunomodulator medication $(\mathrm{N}=188)$} \\
\hline Yes & 145 & 77.1 & & & \\
\hline No & 43 & 22.9 & & & \\
\hline \multicolumn{6}{|c|}{ Extrinsic motivation to use the immunomodulator medication $(\mathrm{N}=188)$} \\
\hline Yes & 166 & 88.3 & & & \\
\hline No & 22 & 11.7 & & & \\
\hline \multicolumn{6}{|c|}{ Perception of the benefits of the immunomodulator medication $(N=188)$} \\
\hline Yes & 104 & 55.3 & & & \\
\hline No & 84 & 44.7 & & & \\
\hline \multicolumn{6}{|l|}{ Side effects $(\mathrm{N}=188)$} \\
\hline Yes & 104 & 60.6 & & & \\
\hline No & 84 & 39.4 & & & \\
\hline \multicolumn{6}{|l|}{ Symptoms of side effects $(\mathrm{N}=104) *$} \\
\hline Myalgia & 52 & 50.0 & & & \\
\hline Malaise & 50 & 48.1 & & & \\
\hline Cephalgia & 42 & 40.3 & & & \\
\hline Fatigue & 35 & 33.7 & & & \\
\hline Fever & 26 & 25.0 & & & \\
\hline Hyperemia & 26 & 25.0 & & & \\
\hline \multicolumn{6}{|c|}{ Difficulty to administer the immunomodulator medication $(\mathbf{N}=\mathbf{1 8 8})$} \\
\hline Yes & 76 & 40.4 & & & \\
\hline No & 112 & 59.6 & & & \\
\hline \multicolumn{6}{|c|}{ Difficulty to obtain the immunomodulator medication $(\mathrm{N}=188)$} \\
\hline \multicolumn{6}{|c|}{ Yes } \\
\hline & 39 & 20.8 & & & \\
\hline No & 149 & 79.2 & & & \\
\hline \multicolumn{6}{|c|}{ Received information about the disease? $(\mathrm{N}=188)$} \\
\hline Yes & 159 & 84.6 & & & \\
\hline No & 29 & 15.4 & & & \\
\hline \multicolumn{6}{|c|}{ Received information about the treatment? $(\mathrm{N}=188)$} \\
\hline Yes & 169 & 90.0 & & & \\
\hline No & 19 & 10.0 & & & \\
\hline \multicolumn{6}{|l|}{ Contacted the doctor $(\mathrm{N}=188)$} \\
\hline By phone and on the day of the consultation & 112 & 59.6 & & & \\
\hline On the day of the consultation only & 76 & 40.0 & & & \\
\hline \multicolumn{6}{|l|}{ Missed any consultations $(\mathrm{N}=188)$} \\
\hline Yes & 93 & 49.5 & & & \\
\hline No & 95 & 50.5 & & & \\
\hline
\end{tabular}

*There is more than one answer. 


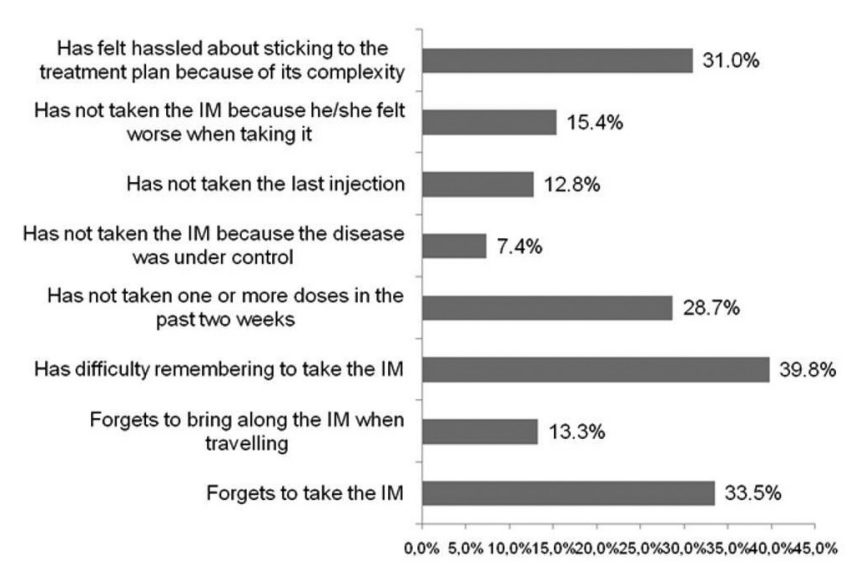

FIGURE 1 - Frequency of positive answers in Morisk 8-item scale in the cognitive function (National Multiple Sclerosis Society, 2006).

Changes in the cognitive function are a very common symptom of MS that affects $62.4 \%$ of patients (Fricska-Nagy et al., 2016). Other study has also observed that the main cause of non-adherence reported by patients with MS was forgetfulness (Devonshire et al., 2011).

It was observed that age (under 39 years old) was statistically significant, corroborating with Fernandez et al. (2012). It is believed that the disease progression hinders adherence by older people. According to the World Health Organization (2003), low adherence affects all age groups. However, the prevalence of functional and cognitive impairment in older patients increases the risk of low adherence.

TABLE III - Association between adherence and the variables adjusted in the logistic regression model divided into blocks. Ceará, 2012

\begin{tabular}{|c|c|c|c|c|c|c|c|}
\hline \multirow[b]{2}{*}{ Variables } & \multirow[b]{2}{*}{ Adherence \% } & \multicolumn{3}{|c|}{ Unadjusted } & \multicolumn{3}{|c|}{ Adjusted } \\
\hline & & $\begin{array}{l}\text { Odds } \\
\text { Ratio }\end{array}$ & $95 \%$ CI & P Value & $\begin{array}{l}\text { Odds } \\
\text { Ratio }\end{array}$ & $95 \%$ CI & P Value \\
\hline \multicolumn{8}{|l|}{ Age (years) } \\
\hline $18-38$ & 53.0 & 1.9 & $1.0-3.5$ & 0.03 & 2.3 & $1.2-4.4$ & 0.01 \\
\hline $39-66$ & 37.5 & & & & & & \\
\hline \multicolumn{8}{|l|}{ Gender } \\
\hline Men & 37.0 & & & & & & \\
\hline Women & 48.6 & 1.6 & $0.8-3.4$ & 0.17 & 1.2 & $0.6-2.6$ & 0.64 \\
\hline \multicolumn{8}{|l|}{ Education } \\
\hline Elementary/High school & 41.2 & & & & & & \\
\hline Higher education & 48.5 & 1.3 & $0.7-2.5$ & 0.32 & 1.2 & $0.6-2.6$ & 0.65 \\
\hline \multicolumn{8}{|l|}{ Employment } \\
\hline Unemployed & 44.9 & & & & & & \\
\hline Employed & 46.9 & 1.1 & $0.6-2.0$ & 0.78 & 1.0 & $0.5-2.0$ & 0.93 \\
\hline \multicolumn{8}{|l|}{ Household income (R\$) } \\
\hline Up to $2.214,89$ & 44.0 & & & & & & \\
\hline Above $2.214,89$ & 51.0 & 1.3 & $0.7-2.7$ & 0.40 & 1.2 & $0.5-2.6$ & 0.68 \\
\hline \multicolumn{8}{|l|}{ Economic status } \\
\hline $\mathrm{A} / \mathrm{B}$ & 47.7 & 1.2 & $0.7-2.3$ & 0.51 & 1.1 & $0.5-2.4$ & 0.75 \\
\hline $\mathrm{C} / \mathrm{D}$ & 42.9 & & & & & & \\
\hline \multicolumn{8}{|c|}{ Expanded Disability Status Scale } \\
\hline $0-3.5$ & 52.8 & 2.3 & $1.2-4.7$ & 0.01 & 2.1 & $1.1-4.1$ & 0.02 \\
\hline $4-8.0$ & 32.3 & & & & & & \\
\hline \multicolumn{8}{|l|}{ Period of diagnosis (months) } \\
\hline 6- 24 & 62.9 & 2.4 & $1.0-5.6$ & 0.02 & 1.9 & $0.8-4.1$ & 0.12 \\
\hline More than 24 & 41.4 & & & & & & \\
\hline \multicolumn{8}{|c|}{ Length of treatment (months) } \\
\hline $6-24$ & 59.5 & 2.0 & $1.0-4.4$ & 0.04 & 2.6 & $1.2-5.8$ & 0.02 \\
\hline More than24 & 41.8 & & & & & & \\
\hline \multicolumn{8}{|c|}{ Intrinsic motivation to use the immunomodulator medication } \\
\hline Yes & 55.9 & 9.6 & $3.5-32.8$ & $<0.0001$ & 8.5 & $3.0-23.8$ & $<0.00$ \\
\hline No & 11.6 & & & & & & \\
\hline
\end{tabular}


TABLE III - Association between adherence and the variables adjusted in the logistic regression model divided into blocks. Ceará, 2012 (cont.)

\begin{tabular}{|c|c|c|c|c|c|c|c|}
\hline \multirow{2}{*}{ Variables } & \multirow[b]{2}{*}{ Adherence \% } & \multicolumn{3}{|c|}{ Unadjusted } & \multicolumn{3}{|c|}{ Adjusted } \\
\hline & & $\begin{array}{l}\text { Odds } \\
\text { Ratio } \\
\end{array}$ & $95 \%$ CI & P Value & $\begin{array}{l}\text { Odds } \\
\text { Ratio }\end{array}$ & $95 \% \mathrm{CI}$ & P Value \\
\hline \multicolumn{8}{|c|}{ Extrinsic motivation to use the immunomodulator medication } \\
\hline Yes & 50.6 & 10.2 & $2.3-92.3$ & 0.00 & 5.9 & $1.2-28.5$ & 0.03 \\
\hline No & 9.1 & & & & & & \\
\hline \multicolumn{8}{|c|}{ Perception of the benefits of the immunomodulator medication } \\
\hline Yes & 61.1 & 4.5 & $2.3-8.9$ & $<0.00$ & 4.9 & $2.5-9.5$ & $<0.00$ \\
\hline No & 26.2 & & & & & & \\
\hline \multicolumn{8}{|l|}{ Side effects } \\
\hline No & 45.9 & 1.0 & $0.5-1.9$ & 0.96 & 1.16 & $0.6-2.3$ & 0.66 \\
\hline Yes & 45.6 & & & & & & \\
\hline \multicolumn{8}{|c|}{ Difficulty to administer the immunomodulator medication } \\
\hline No & 50 & 1.5 & $0.8-2.9$ & 0.16 & 1.53 & $0.7-3.2$ & 0.25 \\
\hline Yes & 39.5 & & & & & & \\
\hline \multicolumn{8}{|c|}{ Difficulty to obtain the immunomodulator medication } \\
\hline No & 48.6 & 1.6 & $0.8-3.4$ & 0.17 & 1.0 & $0.5-2.2$ & 0.95 \\
\hline Yes & 37.0 & & & & & & \\
\hline \multicolumn{8}{|l|}{ Received information about the disease? } \\
\hline Yes & 49.7 & 3.1 & $1.2-9.1$ & 0.01 & 2.47 & $0.6-9.5$ & 0.19 \\
\hline No & 24.1 & & & & & & \\
\hline \multicolumn{8}{|l|}{ Received information about the treatment? } \\
\hline Yes & 47.3 & 1.9 & $0.7-6.5$ & 0.19 & 1.0 & $0.2-5.1$ & 0.94 \\
\hline No & 31.6 & & & & & & \\
\hline \multicolumn{8}{|c|}{ Who administers the immunomodulator medication } \\
\hline Self-administered & 47.8 & 1.2 & $0.7-2.3$ & 0.50 & 0.8 & $0.4-1.7$ & 0.64 \\
\hline Family/other & 42.7 & & & & & & \\
\hline \multicolumn{8}{|l|}{ Changes in lifestyle } \\
\hline Yes & 46.6 & 1.1 & $0.6-1.9$ & 0.86 & 1.1 & $0.6-2.3$ & 0.63 \\
\hline No & 45.2 & & & & & & \\
\hline \multicolumn{8}{|l|}{ Contacted the doctor } \\
\hline By phone and on the day of the consultation & 55.3 & 1.90 & $1.0-3.6$ & 0.031 & 1.95 & $1.0-3.8$ & 0.05 \\
\hline On the day of the consultation only & 39.3 & & & & & & \\
\hline \multicolumn{8}{|l|}{ Missed any consultations } \\
\hline No & 62.4 & 4.0 & $2.1-7.6$ & $<0.00$ & 4.3 & $2.2-8.4$ & $<0.00$ \\
\hline Yes & 29.5 & & & & & & \\
\hline
\end{tabular}

The variables related to the disease suggest that people with lower EDSS scores and shorter periods of diagnosis and length of treatment are more likely to adhere to treatment, corroborating the findings by other authors (Tremlett et al., 2008; Treadaway et al., 2009; Devonshire et al., 2011). Disease progression and the incapacities developed hinder adherence because they interfere directly with the administration of the injection. In addition, cognitive impairment can affect patient's memory and hinder adherence (World Health Organization, 2003; Klauer, Zettl, 2008).
The perception of benefits caused by the use of the immunomodulator is strongly associated with adherence. This is corroborated by other authors (Treadaway et al., 2009; Devonshire et al., 2011) and suggests that the main cause for adherence to the medication is the hope that it will continue to have a positive impact on MS (Turner et al., 2007).

According to the health belief model, one's decision to adopt certain healthy behavior is triggered by the perception of the benefits deriving from certain actions (Kasser, Kosma, 2012). Factors associated with adherence 
are focused on the patient and reflect on individual expectations (Leite, Vasconcellos, 2003).

This study also showed an association between intrinsic motivation and adherence to immunomodulator treatment, which is corroborated by other studies (Turner et al., 2007; Treadaway et al., 2009; Devonshire et al., 2011). One's behavior in certain situations is based on the occurrence of intrinsic and extrinsic motivation (Reiss, 2012). Regarding MS, the intrinsic factor is the patient's motivation to control the disease. The study showed that people who received information about the prognosis and treatment were more intrinsically motivated to adhere to treatment (Apóstolo et al., 2007). Therefore, intrinsic motivation is related to the patient's opportunity to maintain or improve his/her health status. Hoping to get better and reduce the occurrence of episodes and believing that the medication can prevent the disease progression were the main causes of motivation reported by the participants of this study.

Considering the extrinsic motivation, it was observed that the family support to continue the treatment was associated with adherence, a fact that is also highlighted by other authors (Klauer, Zettl, 2008; Treadaway et al., 2009). However, a comprehensive model of adherence to treatment should not only have patients follow the therapy. It should also keep exogenous influences, especially the family support (Klauer, Zettl, 2008). The family should accompany the person with multiple sclerosis during educational activities as decision-making and the difficulties faced by the person can be overcome with support from the family and their support network through therapeutic groups. There was a positive association between adherence and people who received information about the disease from health care professionals (Mohr et al., 2001; Turner et al., 2007). Information can provide patients with the opportunity to participate actively in the decisions about his/her treatment. Understanding his/her own health status can make them see medication treatment as a tool to reduce the harms caused by MS (Saunders et al., 2010).

Although immunomodulators are dispensed free of charge in all Reference Centers in the country, it did not have any influence on the increase in adherence to treatment; however, the characteristics of the study population should be highlighted as the high education and income of participants did not have an impact on the increase in the adherence to immunomodulator treatment. This fact is also observed in other studies on the adherence to treatment of chronic conditions, which is probably related to one's lifestyle rather than being a social influence (Dias et al., 2011)
Another factor that is associated with adherence is the way the relationship between the patient and the health care professional occurs. In this study, people who contacted their doctors more often (by phone, e-mail and on the day of the consultation) were significantly more adherent to the treatment, a finding that has also been observed by Devonshire et al. (2011). The relationship between the health care professional and the patient can influence the acceptance of a therapy and the adherence to it (Tremlett et al., 2008).

Coelho et al. (2005) corroborate higher rates of adherence among people who do not miss consultations. Missing medical appointments may reflect people's difficulty to recognize the importance of the consultation for their health care, leading to the non-adherence to treatment.

A prevalence of white people has been found by studies conducted in Southeastern Brazil (Callegaro et al., 2001; Fragoso, Pereira, 2007). Different results were found in the cities of Recife (Ferreira et al., 2004) and Fortaleza (Teixeira, 2011), which presented a prevalence of pardos (Portuguese word that refers to mixed-race people). This study took into account the self-reported skin color. Therefore, its classification was subjective (Pena et al., 2011).

When assessing employment, it could be observed that more than half of patients did not have any paid jobs, which is also corroborated by Fragosoand Pereira (2007). The disease progression and the physical and mental impairment reduce the autonomy of people with MS. These changes lead to unemployment and early retirement (Mitchell et al., 2005). Most patients have a higher education level, which is above the national educational level - only $20 \%$ of Brazilians have a college degree (Arelaro, 2005).

The findings of this study can be helpful to explain factors associated with adherence among patients with MS and warn health care services about the importance of the development of individual and collective strategies to offer educational support through the provision of information about the disease and treatment. Still, it suggests interventions that shall reduce the barriers related to forgetfulness and it encourages the inclusion of the patient's family in the treatment.

Finally, the present study suggests, as a solution to increase the adherence, the organization of the service: the organization of the multidisciplinary team so that the nurse can train the patient for the self-administration of the immunomodulator through an educational process in which the professional can transmit knowledge about the disease, treatment and self-administration. By building 
this knowledge, patients can become involved in self-care and have greater autonomy in decision-making regarding the adherence to their treatment. Periodic telephone or face-to-face counseling should be carried out in order to investigate adverse effects and good practices of selfadministration of immunomodulators, reinforcing the importance of adherence and encouraging discussion on side effects and difficulties of the treatment. Thus, providing patients with a space for talking and reflecting about their doubts is of utmost importance; additionally, it can improve their knowledge about the disease taking into consideration the reality and feelings of each one.

\section{REFERENCES}

APÓSTOLO, J.L.A.; VIVEIROS, C.; NUNES, H.I.R.; DOMINGUES, H.R.F. Incerteza da doença e motivação para o tratamento em diabetes tipo 2. Rev. Lat.-Am. Enferm., v.15, n.4, p.575-582, 2007.

ARELARO, L.R.G. O ensino fundamental no Brasil: avanços, perplexidades e tendências. Educ. Soc., v.26, n.92, p.10391066, 2005.

ASSOCIAÇÃO BRASILEIRA DE EMPRESAS DE PESQUISA. Critérios de Classificação Econômica Brasil. São Paulo: ABEP, 2012. Available from: <http://www.abep. org/criterio-brasil>. Access on: Jun. 22, 2016.

BRASIL. Portaria SAS/MS n.391, de 05 de maio de 2015. Protocolo Clínico e Diretrizes Terapêuticas (PCDT) da esclerose múltipla. Diário Oficial da União, Brasília, 06 maio 2015. Seção I, p.40.

CALlEGARO, D.; GOLDBAUM, M.; MORAIS, L.; TILBERY, C.P.; MOREIRA, M.A.; GABBA, A.A.; SCAFF, M. The prevalence of multiple sclerosis in the city of São Paulo, Brazil, 1997. Acta Neurol. Scand., v.104, n.4, p.208213, 2001.

COELHO, E.B.; MOISES NETO, M.; PALHARES, R.; CARDOSO, M.C.M.; GELEILETE, T.J.M.; NOBRE, F. Relação entre assiduidade às consultas ambulatoriais e $\mathrm{O}$ controle da pressão arterial em pacientes hipertensos. Arq. Bras. Cardiol., v.85, n.3, p.157-161, 2005.

CONN, V.S.; ENRIQUZ, M.; RUPPAR, T.; CHAN, K.C. Metaanalyses of theory use in medication adherence intervention research. Am. J. Health Behav, v.40, n.2, p.155-171, 2016.
DEVONSHIRE, V.; LAPIERRE, Y.; MACDONELL, R.; RAMO-TELLO, C.; PATTI, F.; FONTOURA, P.; SUCHET, L.; HYDE, R.; BALLA, I.; FROHMAN, E.M.; KIESEIER, B.C. The Global Adherence Project (GAP): a multicenter observational study on adherence to disease-modifying therapies in patients with relapsing-remitting multiple sclerosis. Eur. J. Neurol., v.18, n.2, p.69-77, 2011.

DIAS, A.M.; CUNHA, M.; SANTOS, A.; NEVES, A.; PINTO, A.; SILVA, A.; CASTRO, S. Adesão ao regime terapêutico na doença crônica: revisão da literatura. Millenium, v.40, p.201-219, 2011.

FERNANDEZ, O.; AGÜERA, E.; IZQUIERDO, G.; MILLÁNPASCUAL, J.; TORRENTÀ, L.R.; OLIVA, P.; ARGENTE, J.; BERDEI, Y.; SOLER, J.M.; CARMONA, O.; ERREA, J.M.; FARRÉS, J. Adherence to interferon $\beta-1 b$ treatment in patients with multiple sclerosis in Spain. Plos One, v.7, n. 5, p.1-7, 2012.

FERREIRA, M.L.B.; MACHADO, M.I.M.; VILELA, M.L.; GUEDES, M.J.; ATAIDE, L.; SANTOS, S.; LAURENTINO, S.G. Epidemiologia de 118 casos de esclerose múltipla com seguimento de 15 anos no Centro de Referência do hospital da Restauração de Pernambuco. Arq. Neuro-Psiquiat., v.62, n.4, p.1027-1032, 2004.

FRAGOSO, Y.D.; PEREIRA, M. Prevalence of multiple sclerosis in the city of Santos, SP. Rev. Bras. Epidemiol., v.10, n.4, p.479-482, 2007.

FRICSKA-NAGY, Z.; FÜVESI, J.; RÓZSA, C.; KOMOLY, S.; JAKAB, G.; CSÉPÁNY, T.; JOBBÁGY, Z.; LENCSÉS, G.; VÉCSEI, L.; BENCSIK, K. The effects of fatigue, depression and the level of disability on the health-related quality of life of glatiramer acetate-treated relapsingremitting patients with multiple sclerosis in Hungary. Mult. Scler. Relat. Disord., v.7, p.26-32, 2016.

GORDIS, L. Conceptual and methodological problems in measuring patients compliance. In: HAYNES, R.B. Compliance in health care. Baltimore: Johns Hopkins University, 1989. p.23-45.

KASSER, S.L.; KOSMA, M. Health beliefs and physical activity behavior in adults with multiple sclerosis. Disabil. Health J., v.5, n.4, p.261-268, 2012.

KLAUER, T.; ZETTL, U.K. Compliance, adherence, and the treatment of multiple sclerosis. J. Neurol., v.255, suppl.6, p.87-92, 2008. 
LEITE, S.L.; VASCONCELLOS, M.P.C. Adesão à terapêutica medicamentosa: elementos para a discussão de conceitos e pressupostos adotados na literatura. Cienc. Saude Coletiva, v.8, n.3, p.775-782, 2003.

LÓPEZ-MÉNDEZ, P.; RÍO, J.; PÉREZ-RICART,A.; TINTORÉ, M.; SASTRE-GARRIGA, J.; CARDONA-PASCUAL, I.; GÓMEZ-DOMINGO, M.R.; MONTALBAN, X. Adhesión terapéutica a tratamiento inmunomodulador de pacientes con esclerosis múltiple. Rev. Neurol., v.56, n.1, p.8-12, 2013.

MITCHELL, A.; LÉON, J.; GONZALEZ, J.; RIVERANAVARRO, J. Quality of life and its assessment in multiple sclerosis: integrating physical and psychological components of wellbeing. Lancet Neurol., v.4, n.9, p.556$566,2005$.

MOHR, D.C.; BOUDEWYN, A.C.; LIKOSKY, W.; LEVINE, E.; GOODKIN, D.E. Injectable medication for the treatment of multiple sclerosis: the influence of self-efficacy expectations and injection anxiety on adherence and ability to self-inject. Ann. Behav. Med., v.23, n.2, p.125-132, 2001.

MORISKY, D.E.; ANG, A.; KROUSEL-WOOD, M.; WARD, H.J. Predictive validity of a medication adherence measure in an outpatient setting. J. Clin. Hypertens., v.10, n.5, p.348354, 2008.

NATIONAL MULTIPLE SCLEROSIS SOCIETY. Assessment and management of cognitive impairment in multiple sclerosis. 2006. Available from: <http:// www.nationalmssociety.org/NationalMSSociety/ media/MSNationalFiles/Brochures/Clinical_Bulletin_ Assessment-and-Management-of-Cognitive-Impairmentin-MS.pdf>. Access on: Jun, 22, 2016.

PENA, S.D.J.; DI PIETRO, G.; FUCHSHUBER-MORAES, M.; GENRO, J.P.; HUTZ, M.H.; KEHDY, F.S.G.; KOHLRAUSCH, F.; MAGNO, L.A.V.; MONTENEGRO, R.C.; MORAES, M.O.; MORAES, M.E.A.; MORAES, M.R.; OJOPI, É.B.; PERINI, J.A.; RACCIOPI, C.; RIBEIRO-DOS-SANTOS, Â.K.C.; RIOS-SANTOS, F.; ROMANO-SILVA, M.A.; SORTICA, V.A.; SUAREZKURTZ, G. The genomic ancestry of individuals from different geographical regions of brazil is more uniform than expected. Plos One, v.6, n.2, art.e17063, p.1-9, 2011.

REISS, S. Intrinsic and extrinsic motivation. Teach Psychol., v.39, n.2, p.152-156, 2012.
RIO, J.; COMABElla, M.; MONTALBAN, X. Multiple sclerosis: current treatment algorithms. Curr. Opin. Neurol., v.24, n.3, p.230-237, 2011.

SAUNDERS, C.; CAON, C.; SMRTKA, J.; SHOEMAKER, J. Factors that influence adherence and strategies to maintain adherence to injected therapies for patients with multiple sclerosis. J. Neurosci. Nurs., v.42, n.5, p.S10-S18, 2010.

SOKOL, M.C.; MCGUIGAN, K.A.; VERBRUGGE, R.R.; EPSTEIN, R.S. Impact of medication adherence on hospitalization risk and healthcare cost. Med Care, v.43, n.6, p.521-530, 2005.

TEIXEIRA, C.A.C. Características clínicas e epidemiológica de 146 pacientes com esclerose múltipla acompanhados na cidade de Fortaleza, CE, Brasil, entre os anos 1979 entre os anos 1979 e 2010. Fortaleza, 2011. 227p. Dissertação de Mestrado- Faculdade de Medicina - Universidade Federal do Ceará.

TREADAWAY, K.; CUTTER, G.; SALTER, A.; LYNCH, S.; SIMSARIAN, J.; CORBOY, J. Factors that influence adherence with disease-modifying therapy in MS. J Neurol, v.256, n.4, p.568-576, 2009.

TREMLETT, H.; VAN DER MEI, I.; PITTAS, F.; BLIZZARD, L.; PALEY, G.; DWYER, T.; TAYLOR, B.; PONSONBY, A.L. Adherence to the immunomodulatory drugs for multiple sclerosis: contrasting factors affect stopping drug and missing doses. Pharmacoepidemiol. Drug Saf., v.17, n.6, p.565-576, 2008.

TURNER, A.P.; KIVLAHAN, D.R.; SLOAN, A.P.; HASELKORN, J.K. Predicting ongoing adherence to disease modifying therapies in multiple sclerosis: utility of the health beliefs model. Mult. Scler. J., v.13, n.9, p.1146-1152, 2007.

WOLF, M.S.; DAVIS, T.C.; OSBORN, C.Y.; SKRIPKAUSKAS, S.; BENNETT, C.L.; MAKOUL, G. Literacy, self-efficacy, and HIV medication adherence. Patient Educ. Couns., v.65, n.2, p.253-260, 2007.

WORLD HEALTH ORGANIZATION. WHO. Adherence to long-term therapies: evidence for action, 2003. Disponível em: <http://www.who.int/chp/knowledge/publications/ adherence_Section1.pdf $>$. Acesso em: 22 Jun 2016.

Received for publication on $05^{\text {th }}$ July 2016 Accepted for publication on $03^{\text {rd }}$ November 2016 